\title{
Microcapsules on Streptococcus mutans Serotypes By Electron Microscopy
}

Ella M. Grenier, * R. H. Gray, W. J. Loesche, and W. C. Eveland

The Dental Research Institute, School of Dentistry and Departments of Epidemiology and Environmental and Industrial Health, School of Public Health, University of Michigan, Ann Arbor, Michigan 48109, USA

Extracellular microcapsules have been demonstrated on cells of most serotypes of Streptococcus mutans by electron microscopy, using bacterial strains of the various serotypes and peroxidase labeled or unlabeled immune serum. A correlation was noted between the amount of capsular substance on the strains of $\mathrm{S}$ mutans examined and degree of antigenicity as expressed by the indirect fluorescent antibody (FA) title. A serotype d strain was shown to lose both antigenicity as determined by the $F A$ reaction and capsular material as seen by electron microscopy with repeated in vitro passage. When $10 \%$ unheated rabbit serum was added to the medium, antigenicity and capsular material were restored.

Antisera produced in rabbits to serotypes of Streptococcus mutans gave various titers by fluorescent antibody (FA) techniques, ${ }^{1-3}$ suggesting that there are differences in the degree of antigenicity of the serotypes. Antisera directed against the serotypes of $S$ mutans may cross react with $S$ sanguis and $S$ salivarius. The specificity of the FA reactions can be increased by prior absorption of the sera with the cross reacting antigens. ${ }^{4}$ However, with some $S m u$ tans antisera, the working titer may be so low that cross absorptions will reduce the titer beyond a useful range. An eriochrome black counterstain appears to increase the specificity of the serotypes without the need for cross absorptions. ${ }^{2}$ Both of these procedures, which enhance specificity, do not increase the titer, so that the amount of useful sera is quickly consumed. Higher titers may be achieved by im-

Received for publication May 3, 1976.

Accepted for publication October 12, 1976.

*For reprints: Dr. Ella M. Grenier, Dental Res. Inst. Sch. of Dent., Sch. of Pub. Health, Univ, of Mich., Ann Arbor, Mi. 48104. proving the conditions for isolating specific antibody $y^{5,6}$ or by increasing the antigenicity of the $S$ mutans vaccine. In the present investigation, antigenicity was found to be directly related to the amount of extracellular capsular material on the cells.

\section{Materials and Methods}

Strains.-The strains of $S$ mutans representing the five serotypes ${ }^{1}$ were obtained from Dr. L. A. Thomson (NIDR, Bethesda, $\mathrm{Md})$. These included E49 with $a$ antigen; ${ }^{7}$ BHT with $b$ antigen; ${ }^{8}$ Fa-1 with $b$ antigen; ${ }^{9}$ GS5 with $c$ antigen; ${ }^{10}$ Ingbritt with $c$ antigen; ${ }^{11}$ OIHI with $d$ antigen; ${ }^{12} 6715$ with $d$ antigen; ${ }^{13}$ AHT with $d$ antigen; ${ }^{8}$ LM7 with $e$ antigen; ${ }^{14}$ and $\mathrm{B} 2$ with $e$ antigen. ${ }^{15}$ Strain AHT was originally described as having $a$ antigen. ${ }^{1}$ However, our strain showed a strong $\mathrm{FA}$ reaction with known anti $d$ sera $^{2}$ and behaved biochemically as a serotype $d$ strain. ${ }^{16}$ This strain will be designated as AHT-d. Subsequently an AHT strain was obtained which had been shown by $\%$ guanine:cytosine ratio to belong to the genetic grouping which contained serotype $a$ cells, ${ }^{17}$ and which did not react with group $d$ antisera.

Preparation of vaccines, antisera, fA CONJUGATES AND STAINING.-The preparation of vaccines and antisera as well as the fluorescein conjugation and direct FA staining using eriochrome black as a counterstain were the same as that described by Grenier et al. ${ }^{2}$ Smears of antigen suspensions (vaccines) were made on glass slides, air dried and heat fixed for the indirect FA titrations. Serial dilutions of unconjugated antisera were added and the slides were incubated in a moist chamber for 30 minutes at room temperature. The slides were washed in two changes of phosphate buffered saline (PBS) ( $\mathrm{pH} 7.6)$, rinsed in dis- 
tilled water and air dried. Fluorescein conjugated goat anti-rabbit globulin* 'undiluted) was added, incubated and washed as above. Finally the slides were mounted in buffered glycerine (one part PBS and nine parts glycerine with $\mathrm{pH}$ adjusted to 7.6) and read in a Zieiss GFL microscope. Appropriate control tests were made using smears of the antigen suspensions, normal rabbit serum (pooled) and the conjugated goat anti-rabbit globulin. These control tests were all negative.

Fluorescein/protein ratios were obtained for all of the conjugated antisera, ${ }^{18}$ using a Gilford spectrophotometer, Model 240. All were within the acceptable range of 2 to 10 $\mu \mathrm{g} / \mathrm{mg}^{19}$

Agglutrnation titrations.-Twenty-four hour cultures of the various strains of $S$ mutans were grown in medium containing half strength Brain Heart infusion $\dagger$ and half strength Spirolate Broth $\dagger$ to which $0.5 \%$ yeast extract was added (BHS medium). The cultures were centrifuged 10 minutes at $3,000 \times g$; the supernatant was poured off and the pellet resuspended and washed once with physiologic saline. The cultures were finally diluted to the turbidity of a MacFarland No. 5 standard $\left(1.5 \times 10^{8}\right.$ organisms per millimeter $)$. The suspensions were mixed well and used as the slide agglutinating antigens.

Small aliquots of antisera to the $S$ mutans strains were heated at $56 \mathrm{G}$ each day before use. Doubling dilutions of the antisera were made in Kahn tubes, starting with $0.2 \mathrm{ml}$ saline and $0.2 \mathrm{ml}$ serum. The antiserum dilutions, $0.05 \mathrm{ml}$ each, were pipetted into circled areas on the slides. Saline (no antiserum) was pipetted into one circle to serve as an antigen control. Then, $0.25-\mathrm{ml}$ antigen suspension was added to each circle of antiserum and to the antigen control. Slides were rotated four minutes at 160 RPM on a platform shaker. Tests were read immediately in a light microscope at $100 \times$ magnification.

Peroxidase conjugation.--Sampies of antisera to strains AHT- $d, \mathrm{Fa}-1, \mathrm{GS} 5, \mathrm{LM} 7, \mathrm{~B} 2$ as well as goat anti-rabbit serum were conjugated with peroxidase. The globulin fraction was precipitated from the antisera in $33 \%$ saturated ammonium sulfate. ${ }^{20}$ The precipitate was dissolved in water (the same amount as the original volume of antiserum) and reprecipitated in $33 \%$ saturated ammonium sulfate. The

\footnotetext{
* Sylvania Company, Millburn, $\mathrm{NJ}$.

$\dagger$ Bioquest

+ Type 1, Sigma Chemical Co., St. Louis, Mo.
}

final precipitate was dissolved in physiologic saline (half the original volume of antiserum) and dialyzed overnight in PBS ( $\mathrm{pH} \mathrm{7.6)} \mathrm{to}$ remove sulfate ions. The protein content of the retentate was determined by the Biuret method with the spectrophotometer at 540 $\mathrm{nm} .{ }^{21}$

Twelve milligrams of horseradish peroxidase $\$$ were added to a solution containing 5 $\mathrm{mg}$ of globulin (protein) in $1 \mathrm{ml}$ of $0.1 \mathrm{M}$ phosphate buffer (pH 6.8) ${ }^{22}$ Then $0.05 \mathrm{ml}$ of $1 \%$ glutaraldehyde (coupling agent) was added while shaking and the mixture allowed to stand at room temperature for two hours. The conjugate was dialyzed overnight in two changes of PBS ( $\mathrm{pH} 7.6)$, and centrifuged at $10,000 \times g$ for 30 minutes in a Lourdes refrigerated centrifuge. Finally the conjugates were filter sterilized through a Morton ultra-fine sintered glass filter and stored at $4 \mathrm{C}$.

Peroxidase staining.--A sufficient amount of vaccine or culture was placed in a sterile Kahn tube to give a pellet after centrifugation of about a half millimeter thick. To each sample $0.1 \mathrm{ml}$ of appropriate peroxidase conjugated antiserum was added, mixed and allowed to stand 30 minutes at room temperature. The samples were centrifuged at $3000 \times \mathrm{g}$ for 10 minutes; the supernatant was pipetted off and the pellet was washed once with PBS $(\mathrm{pH} 7.6)$ and again centrifuged. After pipetting off the supernatant fluid, each sample was stained with $1 \mathrm{ml}$ of a solution containing $5 \mathrm{mg}$ of 3,3'-diaminobenzidine tetrahydrochloridet in $10 \mathrm{ml}$ PBS ( $\mathrm{pH} \mathrm{7.6)}$ to which $0.01 \%$ hydrogen peroxide ( $1 \mathrm{ml}$ of $0.1 \%$ ) was added immediately before use. ${ }^{20}$ The preparations were centrifuged and washed once as above.

EleCtron microscopy.-After the peroxidase staining, the bacterial cells were pelleted and immediately resuspended in $3 \%$ glutaraldehyde containing $0.1 \mathrm{M}$ phosphate buffer ( $\mathrm{pH}$ 7.2) for 1-2 hours at room temperature. The cells were washed three times in $0.1 M$ phosphate buffer containing $0.2 M$ sucrose and stored overnight in this mixture. The following day the cells were postfixed in $2 \%$ osmium tetroxide in $0.1 M$ phosphate buffer, dehydrated in a graded ethanol series, infiltrated with propylene oxide and Epon and embedded in Luft's Epon mixture. Sections were made with a diamond knife on a Reichert Om-U2 ultramicrotome. For each preparation, one grid was poststained with uranyl magnesium acetate $^{23}$ and lead citrate ${ }^{24}$ and one was not poststained. Grids were examined and photo- 
graphed with an AEI-Cornith 275 electron microscope.

Macrophage culture and Staining.Rabbit alveolar macrophages were obtained by a modification of a method described by Myrvik, Leake and Fariss. ${ }^{25}$ New Zealand white rabbits weighing between 2 and $3 \mathrm{~kg}$ were sacrificed by injecting $10 \mathrm{ml}$ of air into the marginal ear vein. The thoracic cavity was opened and the upper part of the trachea was transected. The lungs, heart and trachea were dissected as a single unit. Thirty $\mathrm{ml}$ of Hanks balanced salt solution (HBSS) containing 10 units of heparin per milliliter were slowly injected with a syringe through a 20gauge needle (bevel removed) between two tracheal rings. The fluid was withdrawn and placed in a large centrifuge tube. The procedure was repeated again and recovered in the same manner.

The yield of macrophages was determined by counting the cells in a hemacytometer. The viability of the cells was determined by suspending an equal volume of cells in $0.2 \%$ trypan blue and counting in a hemacytometer.

\# Microbiological Associates, Bethesda, Md.
In all experiments, 95-99\% of the macrophages excluded the trypan blue dye. Differential counts were made on Wright's stained smears; it was found that about $95 \%$ of the cells were macrophages.

Macrophages were suspended in Tissue Culture Medium 199\# ( $\mathrm{pH}$ adjusted to 7.2 with $1.4 \%$ sodium bicarbonate) containing 100 $\mu / \mathrm{ml}$ penicillin $\mathrm{G}$ and $100 \mu \mathrm{g} / \mathrm{ml}$ streptomycin and $20 \%$ normal, inactivated rabbit serum to a concentration of approximately $5 \times 10^{5}$ cells/ $\mathrm{ml}$.

Shaker and roller tube cultures were used initially. Formalin-fixed cells of all five serotypes of $S$ mutans were added $\left(0.1 \times 10^{7}\right)$ to macrophages and allowed to incubate 3 hours or 24 hours at $37 \mathrm{C}$.

Later cultures were grown in Leighton tubes with a $9 \times 35 \mathrm{~mm}$. cover slip and incubated at $37 \mathrm{C}$ for 24 hours for attachment and stabilization. The next day the medium was removed and cells were washed two times with HBSS and fresh medium added with $20 \%$ normal or immune rabbit serum. Formalinfixed cells of all five serotypes of $S$ mutans were added $\left(0.1 \times 10^{7}\right)$ to macrophages and al-

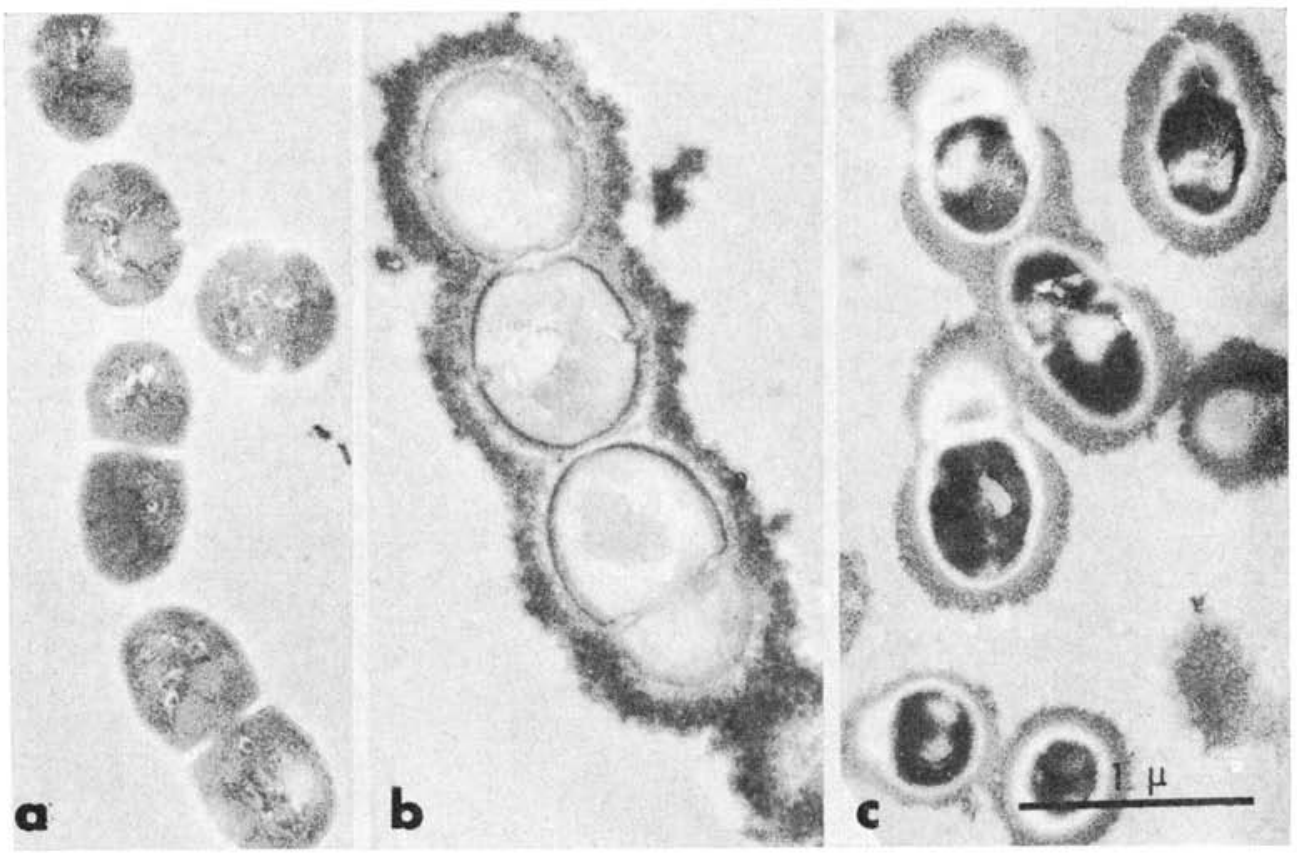

Fig 1.-Electron micrographs of thin sections of $S$. mutans. All preparations were poststained with uranyl magnesium acetate and lead citrate. Magnification is $\times 25,000$. (a) Strain
AHT- $d$ with no antiserum. (b) Strain AHT- $d$ treated with AHT- $d$ peroxidase conjugated antiserum. (c) Strain AHT- $d$ treated with AHT- $d$ unlabeled antiserum. 
lowed to incubate 4 hours at $37 \mathrm{C}$. The cover slip preparations were washed again in HBSS, fixed in absolute methanol for 10 minutes, air dried and then stained with May-GrunwaldGeisma stain. ${ }^{26}$ Stained cover slips were mounted with Mounting Medium' and examined in a light microscope with oil immersion $100 \times$ objective. On each preparation 100 macrophages were examined for phagocytosis.

\section{Results}

The morphology of untreated AHT- $d$ cells by transmission electron microscopy can be seen in Figure 1a. There is no evidence of capsular or extracellular material around the cells. However, when the same AHT- $d$ cells were treated with homologous immune serum that had been conjugated with peroxidase, an electron-dense layer (approximately $200 \mathrm{~nm}$ ) was evident (Fig 1b). When the AHT- $d$ cells were treated with unconjugated antiserum (Fig 1c), a finer consistency was seen when compared with the coarse particles of the peroxidase labeling. 'These electron-dense layers were just as evident in sections which were not poststained with uranyl magnesium acetate and lead citrate. However, this layer could not be demonstrated by India ink preparations or by Quellung reaction using lightfield or dark-field microscopy. ${ }^{27}$

The AHT- $d$ peroxidase conjugate did not stain extracellular material on $S$ sanguis cells, strain 10556, or $S$ salivarius cells, strain HHT (Table 1). When AHT- $d$ cells were treated with pooled normal rabbit serum followed by peroxidase-labeled goat anti-rabbit serum and poststained with uranyl acetate and lead ci-

\footnotetext{
/ Technicon Chemical Co., Inc., Chauncey, NY.
}

trate, there was no evidence of extracellular staining (Table 1).

Representative strains of Streptococcus mutans serotypes $a, b, c, d$, and $e$ were also treated with the AHT- $d$ peroxidase conjugated antiserum and the electron micrographs showed varying amounts of labeled extracellular substance. AHT- $a$ cells (Fig 2a) showed less extracellular material (ECM) than AHT-d cells (Fig 1b). The Fa-1 cells (serotype $b$ ) showed very little ECM (Fig 2b); Ingbritt cells (serotype $c$ ) seemed to be a mixture of cells with and without ECM (Fig 2c); OIHI cells (serotype $d$ ) showed a considerable amount of ECM on every cell (Fig 2d) and the LM7 cells (serotype $e$ ) appeared to have no ECM. When these cells were reacted with peroxidase conjugated homologous antisera, essentially the same degree of ECM reactions were seen as those described with the AHT- $d$ peroxidase conjugate.

Table 2 shows a comparison of the titers obtained by agglutination tests, direct and indirect FA tests using homologous cells and antisera, and the relative amounts of ECM as seen in the electron micrographs after staining with either the AHT-d peroxidase conjugate, or with homologous peroxidase conjugates. There seemed to be no correlation between the agglutination titers and the FA titers. This was also found by Griffin ${ }^{28}$ using nonspore-forming anaerobes. The indirect FA titers were higher than the direct with every strain except BHT and LM7. The serotype $d$ strain exhibited a fourfold increase with the indirect FA test. The relative amount of ECM as estimated by staining with the AHT-d peroxidase conjugated antiserum seemed to parallel direct and indirect FA titers.

TABLE 1

Speaificity of Immune Serum

\begin{tabular}{|c|c|c|c|}
\hline Cells & & Conjugates & Capsular Reaction \\
\hline $\begin{array}{l}S \text { mutans (AHT- } d \text { ) } \\
S \text { mutans (AHT- } d)\end{array}$ & plus & $\begin{array}{l}\text { AHT- } d \text { immune } \\
\text { serum-peroxidase }\end{array}$ & $\begin{array}{l}\text { no capsule } \\
\text { capsule }\end{array}$ \\
\hline$S$ sanguis $(10556)$ & plus & $\begin{array}{l}\text { AHT- } d \text { immune } \\
\text { serum-peroxidase }\end{array}$ & no capsule \\
\hline$S$ salivarius (HHT) & plus & $\begin{array}{l}\text { AHT- } d \text { immune } \\
\text { serum-peroxidase }\end{array}$ & no capsule \\
\hline$S$ mutans (AHT-d) & plus & $\begin{array}{l}\text { pooled normal rabbit serum } \\
\text { and goat anti-rabbit serum- } \\
\text { peroxidase }\end{array}$ & no capsule \\
\hline
\end{tabular}


In subsequent studies, the AHT- $d$ strain that had been repeatedly passed in BHS broth failed to give a FA reaction with the original AHT- $d$ antiserum (Table 3 ) and exhibited a minimal reaction with the AHT- $d$ peroxidase conjugate (Fig 3a). This suggested that the
AHT- $d$ strain had lost, upon laboratory passage, the antigen(s) that had been present in the original AHT- $d$ vaccine and that were responsible for both the FA and the ECM reaction. This could have been caused by the routine selection of nonadherent cells by the
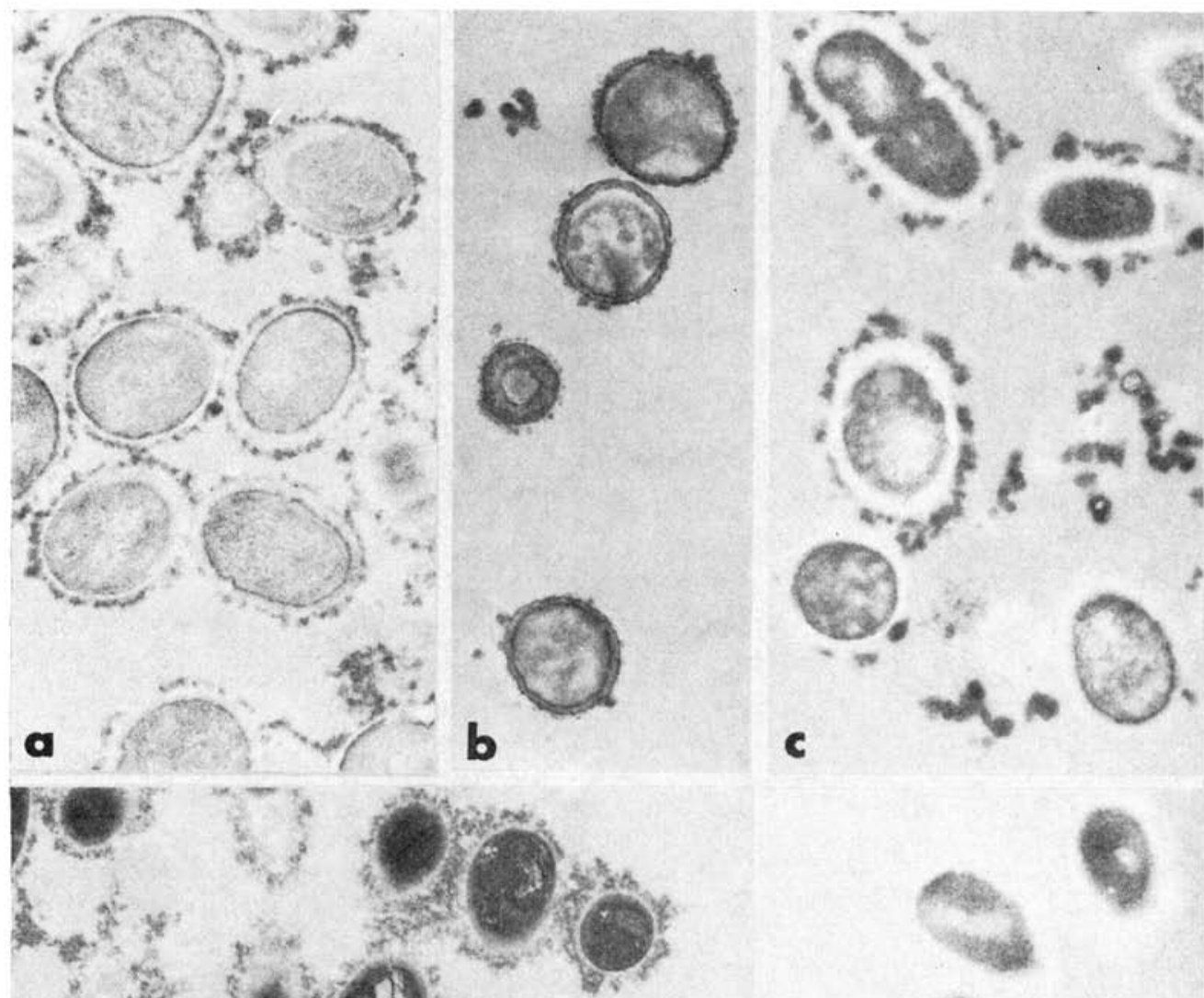


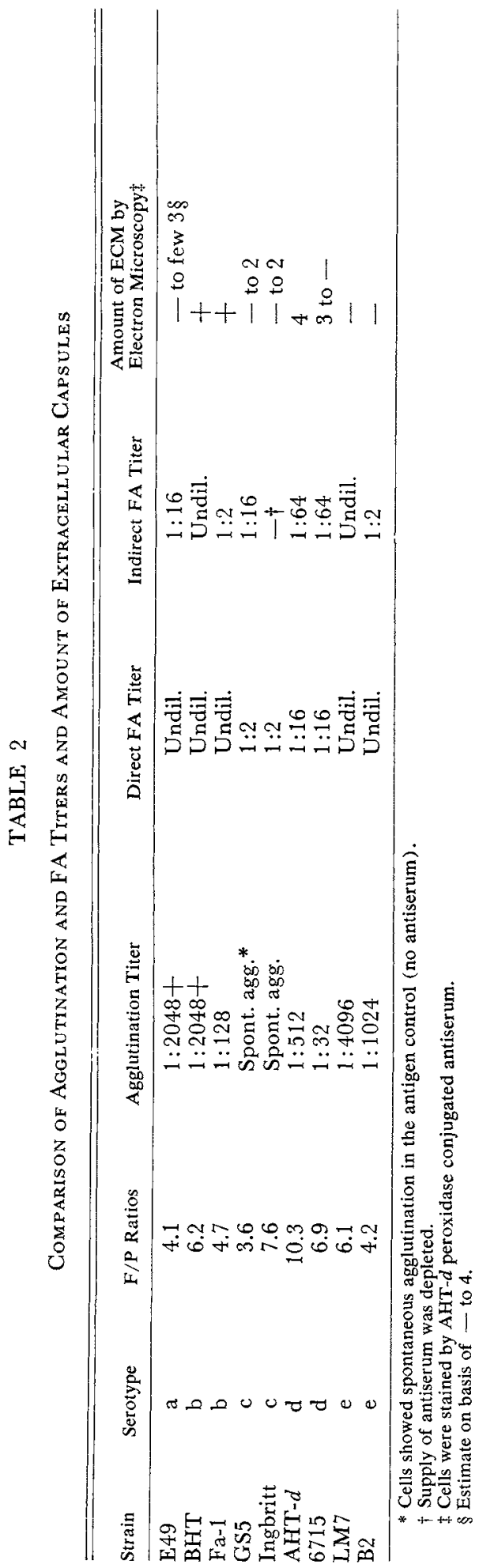

transfer process, which picked cells suspended in the medium and left behind those sticking to the glass walls of the test tubes. A new vaccine, prepared with the repeated passage of AHT-d cells, failed to elicit an antiserum with a satisfactory FA titer, confirming the supposition that laboratory passage had resulted in the loss of antigenic determinant(s). As this antigen appeared to be associated with the ECM, the possibility existed that the ECM could be a microcapsule. ${ }^{27}$ Therefore, efforts were made to enhance capsule formation in this strain. The addition of $10 \%$ unheated rabbit serum to the BHS medium ${ }^{29}$ resulted, after three passages of AHT- $d$, in the restoration of the FA reaction (Table 3) and the ECM formation as seen in the electron microscope with the peroxidase conjugate (Fig 3b). An antiserum, made in rabbits, to the $A H T-d$ restored cells showed a direct FA titer of $1: 16$. Thus, the unheated rabbit serum had restored ECM and antigenicity to the AHT- $d$ repeated passage cells. Heated rabbit serum ( $56 \mathrm{C}$ for 30 minutes) was also tried as a medium supplement but was not as effective as the unheated serum.

A lyophilized sample of our original AHT$d$ strain was rehydrated and grown in the BHSrabbit serum medium. This revived strain had a copius amount of capsule (Fig 3c) and gave a strong FA reaction (Table 3 ). This suggested that the low FA titers obtained with the other serotypes (Table 2) might be improved by growing those cells in rabbit serum. This was done using one strain each of the five serotypes.

The possibility that serum protein could be adsorbed to the cells thereby presenting new antigenic determinants to the host had to be considered. Strains of the five serotypes of $S$ mutans were subcultured three times in BHS medium with or without the addition of rabbit serum. The cultures were centrifuged and the cells suspended in physiologic saline. The cells were tested with conjugated antisera made to the serotypes grown in medium with rabbit serum. Table 4 shows the direct FA reactions using the cell preparations and the conjugated antisera. Fluorescent staining occurred only with the serotype homologous cells and conjugates. Cells grown in the medium with rabbit serum showed stronger FA reactions than those grown in medium without the serum supplement. The reaction on cells of strain 10449 with GS5 conjugate was very weak. There was no overall nonspecificity caused by the addition of rabbit serum.

The effect of growing the cells in the 
TABLE 3

Comparison of FA and Peroxidase Reactions With Cells Grown in Brain-Heart-Spirolate Broth (BHS) With ANd Without Rabbit Serum (RS)

\begin{tabular}{lccc}
\hline \hline \multicolumn{1}{c}{ Cell } & Labeled Antisera Made \\
Designations* & AHT- $d$ Cells Grown in & \multicolumn{2}{c}{$\begin{array}{c}\text { Against AHT- } d \text { Original Cells } \\
\text { FA Reaction }\end{array}$} \\
\hline Reperoxidase Reaction \\
Restored & BHS & \pm & 1 \\
Revived & BHS + RS & 4 & 4 \\
\hline
\end{tabular}

* Repeated-original AHT- $d$ cells passed weekly in BHS.

Restored-repeated passage AHT- $d$ cells grown in BHS + unheated rabbit serum.

Revived-original lyophilized AHT- $d$ cells revived in BHS + unheated rabbit serum.

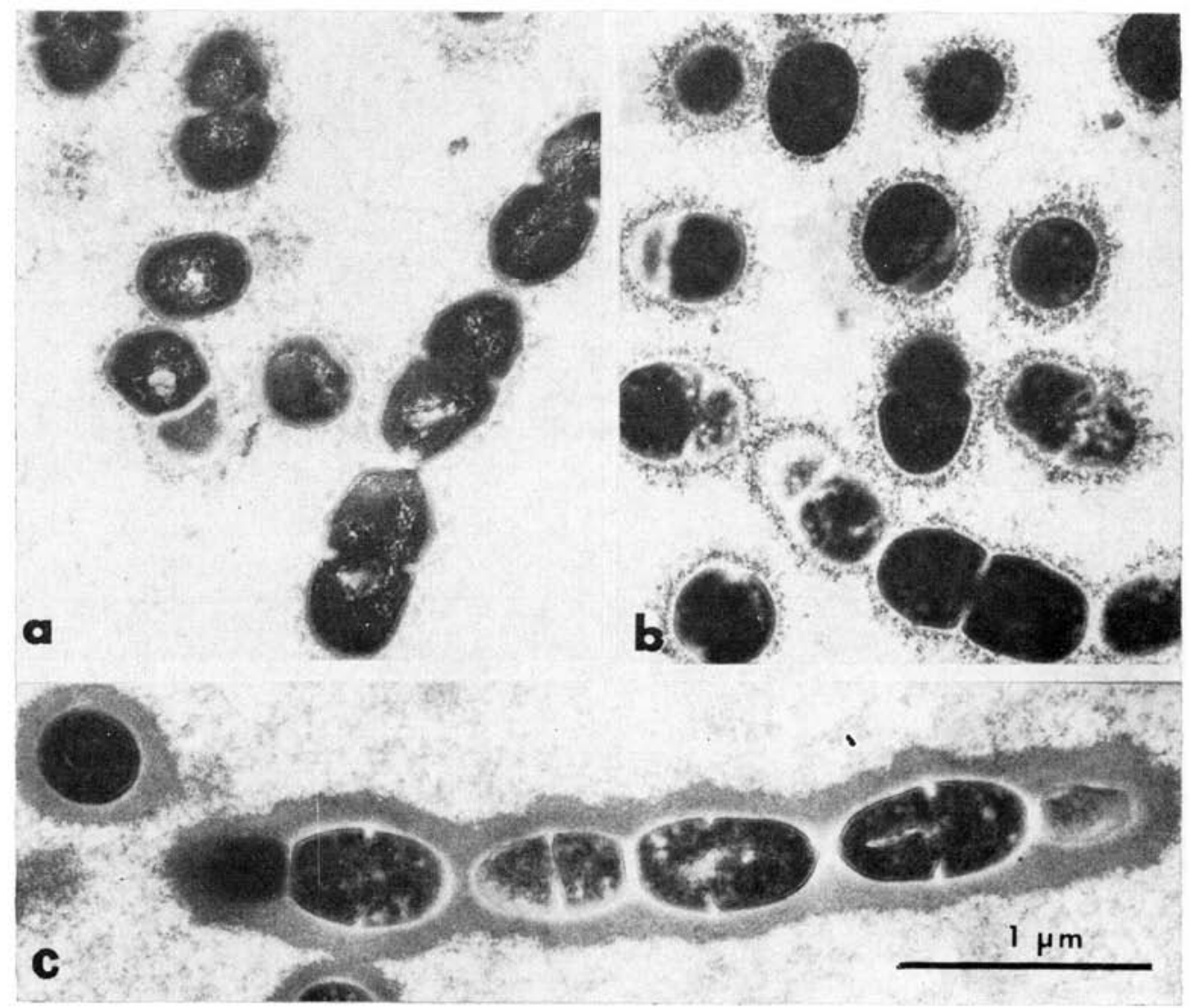

Fig 3.-Electron micrographs of thin sections of $S$ mutans. Magnification is $\times 25,000$. (a) Strain AHT- $d$ (repeated passage) treated with AHT- $d$ peroxidase conjugated antiserum. Not poststained. (b) Strain AHT- $d$ (restored antigenicity) treated with AHT- $d$ peroxidase conjugated antiserum. Poststained. (c) Strain AHT- $d$ (revived antigenicity) treated with unlabeled antiserum to AHT- $d$ restored cells. Poststained. 
TABLE 4

Fa Cross Reactions of Cells Grown in Brain Heart-Spirolate Broth With or Without Rabbit Serum and Fluorescein Conjugated Antisera to Serotypes Grown in Medium with Rabitt Serum-Erioghrome Black Counterstain

\begin{tabular}{|c|c|c|c|c|c|c|c|}
\hline \multirow[b]{2}{*}{$\begin{array}{l}\text { Cells Grown } \\
\text { in BHS + }\end{array}$} & \multirow[b]{2}{*}{ Serotype } & \multicolumn{6}{|c|}{$\begin{array}{c}\text { Conjugated Antisera to Cells Grown in BHS with } \\
\text { Rabbit Serum }\end{array}$} \\
\hline & & $\begin{array}{c}\text { AHT-d } \\
\text { restored } \\
1: 16\end{array}$ & $\begin{array}{l}\text { AHT-d- } \\
\text { revived } \\
1: 8\end{array}$ & $\begin{array}{l}\text { Fa-1 } \\
\text { Undil. }\end{array}$ & $\begin{array}{l}\text { GS5 } \\
\text { Undil. }\end{array}$ & $\begin{array}{l}6715 \\
1: 16\end{array}$ & $\begin{array}{c}\text { B2 } \\
\text { Undil. }\end{array}$ \\
\hline \multicolumn{8}{|c|}{ Rabbit serum- } \\
\hline $\mathrm{E} 49$ & $a$ & - & + & - & - & - & - \\
\hline $\mathrm{Fa}-1$ & $b$ & - & - & 4 & - & - & - \\
\hline GS5 & $c$ & - & - & - & 4 & - & - \\
\hline 10449 & $c$ & - & - & - & \pm & - & - \\
\hline $\mathrm{AHT}-d$ & $d$ & 4 & 4 & - & - & 4 & - \\
\hline OMZ65 & $d$ & 4 & 4 & - & - & 4 & - \\
\hline $\mathrm{B} 2$ & $e$ & - & - & - & - & - & 3 \\
\hline$S$ salivarius & & - & - & - & - & - & - \\
\hline \multicolumn{8}{|l|}{ No Serum- } \\
\hline E49 & $a$ & - & - & - & - & - & - \\
\hline $\mathrm{Fa}-1$ & $b$ & - & - & + & - & - & - \\
\hline GS5 & $c$ & - & - & - & 2 & - & - \\
\hline AHT-d & $d$ & 2 & 2 & - & - & 2 & - \\
\hline OMZ65 & $d$ & 2 & 2 & - & - & 4 & - \\
\hline $\mathrm{B} 2$ & $e$ & - & - & - & - & - & 2 \\
\hline$S$ salivarius & & - & - & - & - & - & - \\
\hline
\end{tabular}

presence of various enzymes on the $F A$ reaction and the ECM was also evaluated. Trypsint $(0.1 \%, 2 \times$ crystallized) reduced but did not eliminate the FA stain for the restored and revived cells, and did not appear to have much of an effect on the ECM. Amylase, $\|$ lipase** and dextranase ti were also tried but had no effect on the FA reaction. Hyaluronidase (7,500 units, bovine testes + +) reduced the FA reaction but did not alter the peroxidase stain.

Limited studies were done to determine the phagocytability of the various serotypes. Rabbit alveolar macrophages were grown overnight in Medium 199 and 20\% normal rabbit serum. When formalin fixed cells of all five serotypes were added (2 to 1) to the washed macrophages, no phagocytosis occurred except with serotype $e$. Every intact macrophage showed phagocytosis of a few cells of serotype $e$ (strain $\mathrm{B} 2$ used) when the reaction took place in shaker and roller tube cultures (Fig

\footnotetext{
I Nutritional Biochemical Corporation.

I| Nutritional Biochemical Corporation.

** Aldrich Chemical Co., Milwaukee, Wi.

$\dagger \dagger$ Sigma Chemical Co., St. Louis, Mo.

\#+ Worthington Biochemical $\mathrm{Co}$.
}

4a). However, when the Leighton tube cultures were used (Fig 4b), the macrophages were engorged with cells. The cover slip preparations obviously offered a better chance for the contact of cells and bacteria. The same results were found when homologous immune sera were used in place of the normal rabbit serum, except that $1 \%$ of the macrophages showed phagocytosis with the AHT-d antiserum and cells.

\section{Discussion}

Strain AHT- $d$ was used extensively in this study because it had a higher working titer in FA tests than the other strains ${ }^{2}$ and the highest $\mathrm{F} / \mathrm{P}$ ratio (Table 2). Its antigenicity may in part be related to the presence of the ECM on the cells of the original vaccine, i.e., electron microscopy of AHT-d revealed ECM which paralleled the intensity of the FA reaction. The ECM was demonstrable by staining with either immune serum or with peroxidase conjugated immune serum. The AHT- $d$ peroxidase conjugated antiserum stained all serotypes of $S$ mutans to the same extent as did each homolo- 

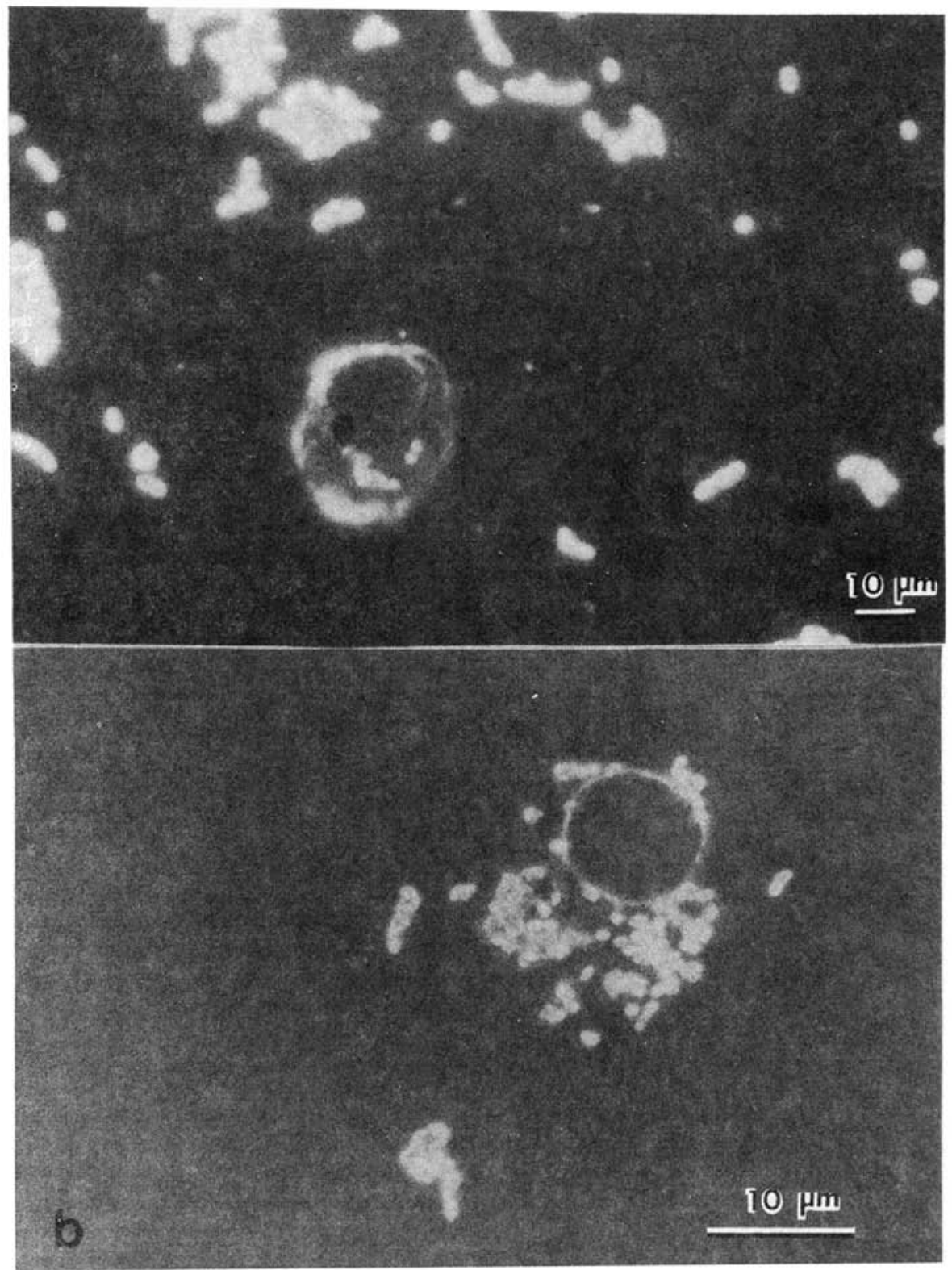

FIg 4.-Photographs of rabbit alveolar macrophages with phagocytized $S$ mutans cells serotype $e$. (a) Macrophages in tissue culture medium and normal rabbit serum. Strain B2 cells were added and shaken three hours at 37 C. Magnification is $\times 750$. (b) Macrophages in tissue culture medium and immune rabbit serum grown in Leighton tubes. Strain B2 cells were added and incubated overnight at $37 \mathrm{C}$. Magnification is $\times 1,875$. 
gous conjugated antiserum by electron microscopy. However, the AHT- $d$ peroxidase conjugate did not stain $S$ salivarius or $S$ sanguis cells.

Serial passage of the AHT- $d$ cultures in BHS resulted in the loss of FA reaction and loss of peroxidase reaction. The addition of the rabbit serum restored antigenicity as measured by both reactions. If the increase in both the FA staining and antigenicity of the streptococcal cells were due to the absorption of serum proteins on the cells' surface, then antibody made against the cells would be nonspecific and react with all the serotypes grown in BHS rabbit serum medium. This was not the case. Cells of the various serotypes after growth in BHS rabbit serum medium were not stained by heterologous antisera (Table 4).

While the addition of unheated rabbit serum did restore antigenicity to the AHT- $d$ cells, the direct FA titer of the conjugated antiserum was no higher than the original titer had been. The indirect FA test could not be used to detect sensitivity after growing the organisms in rabbit serum, as normal proteins on the cells would have been detected as well as specific antiserum that had been produced in rabbits.

The rabbit serum may be exposing the $S$ mutans cells to proteins which they normally meet in vivo either in the saliva ${ }^{30}$ or in gingival crevice fluid. ${ }^{31}$ These serum proteins may stimulate $S$ mutans to form a protective capsule detectable as ECM which enables it to survive more successfully in their presence. In contrast, when the cells are cultured in vitro in the absence of serum proteins, there is no need for capsule formation and this surface antigen is no longer synthesized. This might account for the low antigenicity of $S$ mutans cultures as judged by the $\mathrm{FA}$ reactions. Agglutination titers are not affected by serial passage, indicating that these antigens are distinct from those measured by the $\mathrm{FA}$ reaction. In fact there appears to be an inverse relationship between direct FA titer and the agglutination titer (Table 2).

Phagocytosis studies were undertaken to further demonstrate differences in extracellular material in the cells of the $S$ mutans serotypes. Differences were shown with formalin-killed cells, i.e., strains with ECM were not phagocytized, while the group $e$ strain which had no demonstrable ECM was phagocytized in the presence of normal rabbit serum.

The ECM has several characteristics which suggest that it may be a capsule, i.e.. it is found when the cells are grown in the presence of serum, it is lost upon serial passage and gives the cell some protection from phagocytosis. This capsular material appears to be the antigen that is stained by the fluorescent and peroxidase conjugated antibody as well as the unconjugated antibody. This raises the possibility that $S$ mutans can be identified in situ in plaque.

Lai, Listgarten, and Rosan ${ }^{32}$ have described a capsular reaction on $S$ sanguis using immune serum. In a later report, ${ }^{33}$ the authors have shown by absorption that $c$ and $d$ antigens of $S$ sanguis are located in the extracellular material of this organism. Further they have shown that the "immunocoating reaction" could be used for the in situ identification of $S$ sanguis in dental plaque. Cells showing positive reactions were arranged as pyramidal shaped colonies with the apex at the tooth surface and the base at the surface facing the oral cavity.

\section{Conclusions}

Extracellular microcapsules have been demonstrated on most serotypes of $S$ mutans which might be of significance in the adherence, survival, and pathogenicity of this organism. A nongenetic variation was shown to occur in strain AHT- $d$ resulting in the loss of FA staining and capsular substance, but both were restored by the addition of unheated rabbit serum to the growth medium. It seemed reasonable to assume that other serotypes might also lose the same type of antigenicity in this and other media. This may account for the low titered antisera obtained with some strains of this organism.

We would especially like to thank Mrs. Roberta $\mathrm{K}$. Brabec for her meticulous work in preparing the large number of thin sections used in this study. We also thank Dr. Generosa G. Morales, Department of Health, Manila, for doing agglutination tests with the various strains of Streptococcus mutans. Mr. Samuel Gregorio, graduate student in The University of Michigan School of Public Health, assisted in many aspects of this study.

\section{References}

1. BRatthall, D.: Demonstration of Five Serological Groups of Streptococcal Strain Resembling Streptococcus mutans. Odont Revy 21:143-152, 1970.

2. Grenier, E.M.; Eveland, W.C.; and Loesche, W.J.: Identification of Streptococcus mutans, Serotypes in Dental Plaque by Fluorescent Antibody Techniques. Arch Oral Biol 18:707-715, 1973.

3. ZiNNER, D.D., and JABlon, J.M.: Human streptococcal strains in experimental caries, in Harris, R.S., (ed): The Art and Science of Dental Caries Research, New York, Academic Press, 1968, pp. 87-109. 
4. Bratrhall, D.: Immunofluorescent Identification of Streptococcus mutans. Odont Revy 23:181-196, 1972.

5. Hebert, G.A.; Pittman, B.; MaKinney, R.M. and Cherry, W.B.: The Preparation and Characterization of Fluorescent Antibody Reagents. P.H.S Manual. U.S. Dept. of HEW, CDC, Atlanta, Georgia 30333, 1972.

6. Pittman, B.; Hebert, G.A.; Harris, P.P.; MCKinNey, R.M.; Thacker, L.; and Cherry, W.B.: Preparation and Evaluation of Fluorescent Antibody Reagents for Streptococcus mutans. ASM Preprinted Abstracts. 74th Annual Meeting. Abstract M134, 1974.

7. Fitzgerald, R.J., and Keyes, P.H.: Demonstration of the Etiologic Role of Streptococci in Experimental Caries in the Hamster. JADA $61: 9-19,1960$.

8. Zinner, D.D.; Jablon, J.M.; Aran, A.P.; and SASLAW, M.S.: Experimental Caries Induced in Animals by Streptococci of Human Origin. Proc Soc Expl Biol Med 118:766$770,1965$.

9. Fitzgerald R.J.; Jordan, H.V.; and StanLEY, H.R.: Experimental Caries and Gingival Pathologic Changes in the Gnotobiotic Rat. J Dent Res 39:923-935, 1960.

10. Gibbons, R.J., and Fitzgerald, R.J.: Dextran-Induced Agglutination of Streptococcus mutans, and Its Potential Role in the Formation of Microbial Dental Plaque. I Bacteriol $98: 341-346,1969$.

11. Krasse, B.: Human Streptococci and Experimental Caries in Hamsters. Arch Oral Biol 11:429-436, 1966.

12. Carlsson, J.; Söderholm, G.; and AlmFELDT, I.: Prevalence of Streptococcus sanguis and Streptococcus mutans in the Mouth of Persons Wearing Full Dentures. Arch Oral Biol 14:243-249, 1969.

13. Fitzgerald, R.J.; Keyes, P.H.; Stoudt, T.H.; and Spinell, D.M.: The Effects of a Dextranase Preparation on Plaque and Caries in Hamsters, a Preliminary Report. JADA 76:301-304, 1968.

14. Gibbons, R.J.; Berman, K.S.; Knoettner, R.; and Kapsimalis, B.: Dental Caries and Alveolar Bone Loss in Gnotobiotic Rats Infected with Capsule Forming Streptococci of Human Origin. Arch Oral Biol 11:549_ $560,1966$.

15. Edwardsson, S.: Characteristics of CariesInducing Human Streptococci Resembling Streptococcus mutans. Arch Oral Biol 13: $637-646,1968$.

16. Shklair, I, and Keene, H.: A Biochemical Scheme for the Separation of the Five $\mathrm{Va}$ rieties of Streptococcus mutans. Arch Oral Biol 19:1079-1081, 1974.

17. Coykendali, A.L.: Four types of Streptococcus mutans Based on their Genetic Anti- genic and Biochemical Characteristics. J Gen Microbiol 83:327-338, 1974 .

18. Wells, A.F.; Miller, C.F.; and Nadel, M.D.: Rapid Fluorescein and Protein Assay Method for Fluorescent-Antibody Conjugates. Appl Microbiol 14(2): 271-275, 1966.

19. Goldmax, M.: Fluorescent Antibody Methods, New York, Academic Press, 1968, p. 126.

20. Petrs, V., and Roitt, I.M.: Peroxidase Conjugates for Demonstration of Tissue Antibodies: Evaluation of the Technique. Clin Expl Immunol 9:407-418, 1971.

21. Gornall, A.G.; Bardawill, G.J.; and Davis, M.M.: Determination of Serum Proteins by Means of the Biuret Reaction. $J$ Biol Chem 177:751--766, , 1949.

22. Avrameas, S.: Coupling of Enzymes to Proteins with Glutaraldehyde. Immunochemistry 6:43-52, 1959 .

23. Frasca, J.M., and Parks, V.R.: A Routine Technique for Double Staining Ultrathin Sections Using Uranyl and Lead Salts. $J$ Cell Biol 25:157-161, 1965.

24. Reynolds, E.S.: The Use of Lead Citrate of High $\mathrm{pH}$ as an Electron Opaque Stain in Electron Microscopy. J Cell Biol 17:208212, 1963.

25. Myrvik, O.N.; Leake, E.A.; and Fariss, B.: Studies on Pulmonary Alveolar Macrophages from the Normal Rabbit: A Technique to Procure Them in a High State of Purity. J Immunol 86:128-136, 1961.

26. Merchant, D.J.; KaHN, R.H.; and Murphy, W.H.; Jr.: Handbook of Cell and Organ Culture. 2nd. Ed. Burgess Publishing Co., Minneapolis, Minn., 1969.

27. Wrininsox, J.F.: The Extracellular Polysaccharides of Bacteria. Bacteriol Revs 22: 46-73, 1958.

28. Griffin, M.: Fluorescent Antibody Techniques in the Identification of the GramNegative Nonspore-Forming Anaerobes. Health Lab Science $7: 78-83,1975$.

29. Hanson, A.W., and Cannefax, G.R.: Rehydration of Lyophilized Spirochaetal Cultures. J Bacteriol 88:811, 1964.

30. Lehner, T.; Cardwell, T.; and Clarry, E.: Immunoglobulins in Saliva and Serum in Dental Caries. The Lancet 1294-1297, 1967.

31. Weinstein, E., and Mandel, I.D.: The Fluid of the Gingival Sulcus. Periodontics 2: 149-153, 1964.

32. Lai, C.; Listgarten, M.: and Rosan, B.: Serology of Streptococcus sanguis: Localization of Antigens with Unlabeled Antisera. Infect Immunity 8:475-481, 1973.

33. Rosan; B.; LAI, C.H.; and IIstgarten, M.A.: Streptococcus sanguis: A Model in the Application of Immunochemical Analysis for the Localization of Bacteria in Dental Plaque. I Dent Res (In Press), 1976. 